\title{
KEBIJAKAN DAN EKSPRESI KEBUDAYAAN; SEBUAH DILEMA? (Meninjau Kembali Kebijakan Kontroversial terkait Perempuan dan Ekspresi Kebudayaan)
}

\author{
Iromi Ilham \\ Program Studi Antropologi \\ Universitas Malikussaleh Lhokseumawe Aceh-Indonesia \\ Korespondensi: iromi.ilham@unimal.ac.id
}

\begin{abstract}
Abstrak :Ada kegelisahan yang menyeruak tatkala muncul berbagai kebijakan terkait ekspresi kebudayaan di tengah-tengah masyarakat. Tulisan sederhana ini berusaha untuk membongkar kegelisahan tersebut agar tak mengental yang berakibat tersumbatnya saluran kebudayaan. Kebijakan yang strategis selalu mengacu pada tiga ukuran, yaitu: pertama, memiliki tujuan yang jelas; kedua, mengacu pada konteks tantangan hari ini dan masa depan; dan ketiga, sesuai dengan sumber daya yang dimiliki. Penjaringan partisipasi semua kalangan juga tak kalah penting dalam penentuan kebijakan. Intinya, harapan akhir dari kebijakan publik terkait kebudayaan adalah kebijakan yang membangun keunggulan bersaing dari setiap pribadi rakyat tanpa membedakan gender, ras, agama, dan latar belakang yang berbeda.
\end{abstract}

Kata Kunci: Kebijakan, Kontroversial, Ekspresi Kebudayaan 


\section{A. Pendahuluan}

Tulisan ini berawal dari perjumpaan saya dengan seorang dara di pusat penjualan buku "shopping center", Yogyakarta. Malam itu, ketika saya asik mengepulkan asap rokok di pelataran shopping, seorang gadis yang akhirnya saya ketahui sebagai seorang mahasiswi yang sedang menyelesaikan studi tingkat pascasarjana di salah satu kampus terbaik di Indonesia itu mengajak saya bicara. Ketika ia mengetahui saya berasal dari Aceh, ia langsung nyelutuk "Oh... Provinsi yang ceweknya nggak boleh ngangkang di motor ya mas ...”. Tidak hanya sampai disitu, ia juga melanjutkan "Eh mas... cewek-cewek disana juga nggak boleh nari ya? Kasihan cewek-cewek disana mas". Pernyataan akhir sang dara membuat saya tersenyum simpul "syukurlah Aceh semakin terkenal, walau hanya bersebab peraturan-peraturan kontroversial yang muncul.

Memang, bukanlah sesuatu yang luar biasa ketika ia membicarakan kebijakan Walikota Lhokseumawe yang melarang perempuan duduk mengangkang (ngangkang style) ketika dibonceng di belakang sepeda motor pada Januari 2013.1 Juga bukan sesuatu yang aneh ketika mahasiswi tersebut juga berbicara terkait wacana Bupati Aceh Utara yang mengatur kebijakan mengenai larangan mengekspresikan seni tari terhadap para perempuan dewasa di depan umum², toh ia insan akademis yang dituntut untuk berpikir kritis terhadap pelbagai wacana kebijakan yang dihasilkan oleh pemerintah.

Sebenarnya, kedua isu tersebut sudah lama tenggelam dan bahkan cenderung sudah basi, namun tulisan Anne Francis Okongwu dan Joan P. Mencher yang berjudul The Anthropology of Public Policy: Shifting Terrains kembali membuka ingatan saya akan percakapan singkat dengan gadis ranum di malam yang tak

\footnotetext{
1 Kebijakan ini berupa surat edaran Pemerintah Kota Lhokseumawe yang mengatur larangan perempuan duduk mengangkang di atas sepeda motor -dalam bahasa pergaulan, lebih dikenal dengan istilah ngangkang style-. Surat Edaran bernomor 002/2013, tertanggal 2 Januari 2013, ditandatangani oleh Wali Kota Lhokseumawe Suaidi Yahya, Ketua DPR-Kota Lhokseumawe Saifuddin Yunus, Ketua Majelis Permusyawaratan Ulama (MPU) Lhokseumawe Tgk H Asnawi Abdullah, dan Ketua Majelis Adat Aceh, Kota Lhokseumawe Tgk H Usman Budiman, dan secara resmi diberlakukan tanggal 7 Januari 2013.

2 Terkait dengan larangan menari bagi wanita dewasa di depan umum belum diputuskan dalam dalam bentuk kebijakan tertulis, namun pada tahun 2013, wacana dan isu ini sudah dilemparkan ke publik oleh Bupati Aceh Utara dalam berbagai kesempatan, baik di acara formal, maupun acara nonformal.
} 
berbintang itu. Anne dan Mencher dalam artikelnya melihat ada enam aspek terkait kebijakan yang ingin dikaji, yaitu: (a) hubungan antara proses globalisasi dan kebijakan terhadap level lokal dan nasional, (b) kebijakan kesejahteraan sosial, termasuk kesejahteraan dan strategi bertahan hidup. (c) pengaruh penyesuaian struktural dan restruktur ekonomi migrasi dan kekuatan kelompok pekerja. (d) kebijakan-kebijakan di Negara Utara dan Selatan yang berhubungan dengan pertanian global, ketidakseimbangan sosial, dan manipulasi sebagian perusahaan multinasional. (e) kebijakan-kebijakan yang berdampak pada ketahanan pangan, dan (f) peran para antropolog dalam melihat dampak dari hegemoni politik dan ekonomi (Okongwu and Joan P. Mencher, 2000). Secara tidak langsung, mereka "mempertanyakan" ruang kerja antropolog yang seakan mulai bergeser saat ini.

Hasil penelusuran sederhana, saya mendapati jika perihal peraturan Walikota mengenai ngangkang style sudah banyak pihak yang membahasnya dari berbagai perspektif dan disiplin ilmu, baik di tingkat lokal, maupun nasional. Tulisan-tulisan di dunia akademis, juga sudah lumayan banyak yang membahas isu tersebut, sementara wacana Bupati Aceh Utara yang ingin mengeluarkan kebijakan terkait larangan perempuan mengekspresikan seni tari (pertunjukan seni tari) di depan publik masih sangat sedikit dibahas secara serius di lingkungan akademis. Pembahasan pro-kontra terhadap wacana ini hanya banyak kita dapati di jejaring sosial media dan rubrik opini media massa. Karena itu, saya menjatuhkan pilihan untuk membahas rencana kebijakan Bupati tersebut dalam essai yang singkat ini.

Sebagaimana kita ketahui, Mei 2013 silam, Bupati Aceh Utara, Muhammad Thaib mengeluarkan larangan menari di tempat umum bagi perempuan dewasa. Sebagaimana diberitakan Kompas.com, Bupati yang diusung oleh salah satu partai Lokal di Aceh mengeluarkan instruksi kepada seluruh jajarannya dan juga mensosialisasikannya sendiri secara langsung dalam beberapa acara formal kepada masyarakat terkait dengan larangan bagi perempuan Aceh untuk melakukan tarian adat Aceh karena itu bertentangan dengan Syariat Islam dan merusak norma-norma adat di Aceh (kompas.com, 25 Mei 2013).

Larangan yang direncanakan akan dijadikan perda (peraturan daerah) tersebut menuai pro kontra di kalangan masyarakat Aceh Utara sendiri dan juga menuai kritik dari berbagai kalangan dan tokoh di tingkat nasional. Pelaksanaan Syariat Islam menjadi alasan utama sang Bupati dalam mewacanakan larangan 
tersebut. Pertanyaan mendasar yang muncul adalah apakah pertunjukan seni tari yang dilakoni oleh perempuan bertentangan dengan semangat syariat Islam? Apakah kebijakan yang akan diambil Bupati Aceh Utara sesuai dengan kebutuhan masyarakat Aceh Utara dan tidak bertentangan dengan semangat pelestarian warisan budaya lokal?.

Meskipun belum dikeluarkan dalam bentuk kebijakan yang bersifat mengikat, dalam artian belum di-perda-kan, namun menurut saya tidak salah jika ini dianggap bahagian dari intervensi negara dalam hal kebudayaan yang apabila tidak dikondisikan dengan baik dan penuh pertimbangan, maka akan merugikan banyak pihak dan mematikan kebudayaan lokal itu sendiri. Sebagai bahagian dari masyarakat yang kritis, kita harus bisa menilai dan melihat bagaimana wacanawacana kebudayaan yang terbangun di kalangan elit bangsa ini sehingga setiap kebijakan yang dikeluarkan tidak bias gender dan bias kultur. Dalam catatan Komnas Perempuan, hingga bulan Agustus 2011 terdapat 207 kebijakan diskriminatif atas nama agama dan moralitas di tingkat provinsi dan kabupaten. Sebanyak 78 dari 207 kebijakan tersebut secara khusus menyasar pada perempuan, lewat pengaturan tentang busana (23 kebijakan) dan tentang prostitusi dan pornografi (55 kebijakan) yang justru mengkriminalisasi perempuan (Alimah, 2013).

Semua kondisi ini tidak terlepas dari bentuk demokrasi yang kebablasan melalui otonomi khusus. Perubahan sistem pemerintahan dari sentralistik menjadi desentralistik sebagaimana dalam UU Pemerintahan Daerah No.32/2004 melahirkan "raja-raja kecil" di daerah yang memiliki wewenang sangat luas dalam mengatur daerahnya, termasuk dalam hal perubahan terhadap pengelolaan dan pelestarian warisan budaya bangsa. Perubahan ini berimplikasi pada bergesernya peran pemerintahan pusat, dimana dulunya sebagai penyelenggara tunggal dalam hal pelestarian budaya, selanjutnya hanya berperan sebagai fasilitator dan koordinator.

Berdasarkan Undang-Undang No. 32 tahun 2004 Pemerintah daerah mempunyai hak untuk membuat peraturan daerah. Namun demikian, pasal 135 ayat 4 UU 32/2004 menyatakan bahwa peraturan daerah dilarang bertentangan dengan kepentingan umum dan/atau peraturan perundang-undangan yang lebih tinggi. 
Aceh Anthropological Journal, Vol. 3, No. 1, hlm: 42-56, April 2019

Penyusunan mengenai peraturan daerah disusun juga dalam UU No. 10 tahun 2004 tentang Pembentukan Peraturan Perundang-Undangan.

Kekuasaan elit lokal di daerah menjadi lebih besar, namun idealnya dalam menetapkan sesuatu keputusan dan kebijakan publik, harus melibatkan segala elemen masyarakat sehingga nantinya peraturan yang lahir sesuai dengan kebutuhan dan bisa diterima oleh mayoritas masyarakat, sehingga kebijakan yang lahir membela kepentingan publik secara holistik.

\section{B. Larangan Menari yang Menuai Kritik}

Semenjak wacana tersebut digulirkan ke publik, banyak pihak yang mengkritisi rencana kebijakan yang akan dituangkan dalam bentuk qanun (peraturan) tersebut, diantaranya datang dari pemerhati adat dan seni budaya Aceh, Syamsyuddin. Menurut Ketua Lembaga Forum Budaya Aceh tersebut, jika Bupati Aceh Utara melarang perempuan menari di tempat umum, mengapa tidak ditutup saja semua sanggar seni budaya tarian yang ada di Aceh Utara. Bahkan ia mengklaim jika Bupati Aceh Utara sedang mencari sensasi. Ia mendesak Bupati Aceh Utara untuk memikirkan kembali rencananya tersebut. Menurutnya, jika itu tetap dilakukan maka segala jenis tarian di Aceh akan punah suatu saat (www.bisnisaceh.com, 27 Mei 2013).

Selain itu, pekerja seni yang lain juga melayangkan kritik terhadap wacana larangan menari. Menurut Affandi, kebijakan tersebut sangat tidak berdasar. Menurutnya, kreatifitas seni seorang Muslim memang ada batasnya, tapi jangan menjadikan syariat Islam untuk menyalahkan perbuatan yang dimaksud agar Bupati terlihat berwibawa dan tegas dalam mengaplikasikan syariat Islam di Aceh Utara (Kompas.com, 26 Mei 2013). Nada protes yang sama juga dinyatakan oleh Dwi Rubiyanti Kholifah, direktur Asia Muslim Action Network (AMAN) cabang Indonesia, ia mengkritik otoritas lokal di Aceh yang menyalahgunakan agama. Ia mengatakan "Ada banyak ajaran Islam yang sangat baik dan dapat berguna bagi banyak orang tanpa merusak agama, budaya, dan etnis". Ketua Komisi Nasional Perempuan, Yuniyanti Chuzaifah juga ikut berkomentar, baginya asumsi di balik larangan itu tidak rasional dan keputusan ini tidak hanya menghakimi, tetapi juga 
membuat budaya Aceh tidak berarti (http://khabarsoutheastasia.com, 01 Juni 2013).

Budayawan Aceh, Anton Setiabudi juga angkat bicara. Ia menilai meskipun ini masih bersifat himbauan, namun dampaknya sangat besar bagi para penari di Aceh Utara. Baginya, ini merupakan kemunduran terhadap hak perempuan dalam mengungkap ekspresi estetisnya (www.bbc.co.ukl, 27 Mei 2013). Meskipun banyak yang mengritik, namun juga ada elemen masyarakat yang sepakat dengan larangan tersebut. Misalnya lembaga MUI Aceh Utara yang setuju dengan apa yang digagas oleh orang nomor wahid di Aceh Utara tersebut.

\section{Seni Tari Aceh, Syariat Islam dan Perempuan}

Ahimsa-Putra (2013) mengatakan ada empat jenis wujud kebudayaan, yaitu: pertama, wujud kebudayaan sebagai suatu sistem gagasan, yang di dalamnya terdapat ide, nilai, norma, peraturan, dsb. Kedua, wujud kebudayaan yang berupa aktifitas atau perilaku berpola dari manusia dalam masyarakat, ketiga adalah artefak, atau benda-benda hasil karya manusia, dan keempat adalah sistem kebahasaan (bahasa). ${ }^{3}$ Dalam essai ini, saya hanya membatasi untuk menjelaskan wujud kebudayaan ekspresif dalam bentuk seni tari di Aceh.

Sebagai sebuah daerah yang mengalami akulturasi budaya, Aceh memiliki beragam jenis seni tarian. Disini, saya akan menjelaskan secara singkat terkait beberapa seni tari yang terdapat dalam seni budaya Aceh.

1. Seni tarian Seudati. Seudati berasal dari bahasa Arab yang artinya tuantuanku. Seni ini lahir setelah berdiri masyarakat Islam Aceh yang berfungsi sebagai dakwah dan hiburan. Seudati ini juga terbagi lagi ke dalam beberapa jenis, diantaranya; a) seudati agam, yaitu seudati yang dimainkan oleh lakilaki; b) seudati inoeng, yaitu seudati yang dimainkan oleh perempuan. Seudati inoeng ini juga disebut pho. Pho bermakna ratapan karena menurut

\footnotetext{
${ }^{3}$ Lihat Heddy Shri Ahimsa-Putra. 2013. Budaya Bangsa, Jati Diri dan Integrasi Nasional; Sebuah Teori. Majalah Jejak Nusantara (I). hal. 8.
} 
Aceh Anthropological Journal, Vol. 3, No. 1, hlm: 42-56, April 2019

Hasymi, mulanya tarian ini digunakan untuk meratapi kematian (Hasymi, 1990: 254-255).

2. Tari Saman. Tarian ini paling dikenal secara nasional dan juga dunia internasional diantara seni tari lainnya yang berasal dari Aceh. Tarian ini berasal dari dataran tinggi Gayo. Awalnya, tarian ini ditampilkan dalam perayaan atau acara-acara adat penting dalam masyarakat Aceh. Tarian yang tersinspirasi dari nama seorang ulama besar Aceh, Syech Saman, ditampilkan bersamaan dengan menggunakan iringan alat musik yang berupa gendang dan menggunakan suara dari para penari dan tepuk tangan mereka yang biasanya dikombinasikan dengan memukul dada dan pangkal paha. (Aulia, http://www.scribd.com). Dalam seni tari saman terdapat beberapa gerakan (singkih, lingang, tungkuk, langak, angguk, girik, gerak selalu, gerutup, guncang, dan surang-saring) yang mengiringi ritme rengum, dering, sek, redet, dan saur (Kesuma, 1999: 12-37)

3. Rapai Geleng. Tarian ini ditampilkan oleh laki-laki dan diiringi musik sebagai suara menabuh gendang (rapai).

4. Ratoh Duk (para pemainnya mengekspresikan seni ini sambil duduk) dan Ratoh dong (para pemain mengekspresikan seni ini sambil berdiri)

5. Tarian Ranup Lam Puan. Tarian ini biasanya ditampilkan pada acara-acara adat dan khususnya untuk menyambut tamu-tamu penting yang berkunjung ke Aceh.

Dalam setiap peristiwa kesenian, setidaknya mengandung tiga aspek dasar, yaitu wujud atau rupa (appearance), isi (content/subtance), dan penampilan (presentation). Wujud kesenian adalah perilaku-perilaku atau bentuk (form) dan susunan (structure). Sementara isi kesenian mempunyai tiga aspek, yakni suasana (mood), gagasan (idea), dan ibarat/pesan (message). Penampilan seni terdiri atas tiga unsur yang berperan yaitu bakat (talent), keterampilan (skill), dan sarana atau media (medium/vehicle) (Djelantik, 1999: 17-18).

Yang menjadi titik permasalahan terkait dengan seni tari di Aceh Utara adalah pada subjek yang menampilkan seni tari tersebut. Dimana dalam hal ini perempuan menjadi target dari kebijakan itu. Menurut sang Bupati, gerakan-gerakan yang ada 
Aceh Anthropological Journal, Vol. 3, No. 1, hlm: 42-56, April 2019

dalam perilaku tari jika diperankan oleh perempuan dewasa bertentangan dengan semangat syariat Islam yang sedang dibangun di Aceh. Disamping itu, gerakangerakan tari yang dimainkan wanita juga berhubungan dengan nilai etika dan moral.

\section{Prinsip Kebijakan, Intervensi Negara dan Implikasinya}

Saya sepakat jika campur tangan negara diperlukan dalam usaha memajukan kehidupan manusia dan nilai-nilai kebudayaan. Diantaranya melalui perumusan kebijakan-kebijakan. Karena pemerintah adalah pihak yang bertanggungjawab untuk memajukan segenap kehidupan bangsa dan pemerintah juga berkepentingan dengan kebudayaan dalam arti luas, yaitu seluruh kehidupan manusia dan nilai-nilai kemanusiaannya. Oleh karena itu, dalam menyusun setiap kebijakan, seharusnya pemerintah meletakkan kebudayaan sebagai kaca mata utama (Simatupang, 2013).

Kebijakan menjadi pintu bagi seseorang untuk diakui dan bisa menjalankan peran. Kebijakan hadir sebagai alat untuk mengatur masyarakat yang bersifat topdown melalui pemberian hukuman dan reward. Intinya adalah kebijakan merupakan teknik, pemikiran, dan perilaku yang diputuskan oleh pengambil kebijakan yang bertujuan untuk memberikan solusi atas permasalahan dan menimbulkan perubahan (Shore and Wright, 2005: 5).

Menentukan kebijakan merupakan sesuatu yang rumit dan kompleks. Ia memiliki tehapan-tahapan yang harus dilalui, diantaranya perumusan masalah (defining problem), agenda kebijakan, dan pemilihan alternativ (Winarno, 2005: 8284). Dalam menentukan sebuah kebijakan, pemerintah bukanlah satu-satunya agen tunggal yang melahirkan kebiijakan. Namun pemerintah harus melibatkan aktoraktor yang berkepentingan lainnya sehingga kebijakan yang lahir bisa diterima oleh semua kalangan dan tidak menjadi bumerang bagi pemerintah itu sendiri. Menurut Anderson, dalam praktek perumusan kebijakan, ada dua aktor utama yang terlibat di dalamnya, yaitu: 1) aktor negara atau dalam bahasa Anderson disebut sebagai pembuat kebijakan resmi (official policymaker). Mereka adalah orang-orang yang memiliki kewenangan legal untuk terlibat dalam perumusan kebijakan publik, misalnya agen-agen pemerintah, eksekutif, legislative, dan yudikatif. 2) aktor non Negara atau aktor yang tidak resmi. Mereka adalah kelompok-kelompok yang 
berkepentingan, semisal partai politik, organisasi penelitian, media komunikasi, serta individu masyarakat. Keberadaan mereka juga sangat vital, karena mereka berperan dalam menyediakan informasi; memberikan tekanan; serta mencoba untuk mempengaruhi (Anderson, 2006: 46-67).

Munculnya konflik di kalangan tertentu memang tidak bisa dihindari. Begitu juga dengan konflik atas wacana yang dilempar oleh Bupati Aceh Utara tersebut. Pro kontra yang tidak terkontrol bisa melahirkan konflik fisik yang berbahaya bagi semua pihak. Karena itu, untuk mencegah terjadinya konflik, sebaiknya semua kalangan dan pihak dilibatkan dalam memutuskan sebuah kebijakan di tanah demokrasi. Disamping melibatkan aktor-aktor yang berkepentingan, memperhatikan nilai-nilai juga menjadi sesuatu yang dasar dalam menetukan sebuah kebijakan, yaitu nilai-nilai politik, nilai-nilai organisasi, nilai-nilai pribadi, nilai-nilai kebijakan, dan nilai-nilai ideologis.

Menurut saya, aktor terpenting yang harus dilibatkan adalah masyarakat melalui tokoh adat dan perwakilan mereka melalui organisasi-organisai non pemerintahan. Prinsip partisipatif ini penting sehingga masyarakat yang nantinya juga sebagai target dari kebijakan tersebut merasa memiliki akan kebijakan tersebut dan tidak merasa terpaksa dalam menjalankannya. Kunci kepemilikan ini melalui melibatkan mereka dalam setiap tahap, mulai dari penjaringan aspirasi dan perumusan awal. Pola bottom-up sepertinya cocok diterapkan untuk hal ini. Apalagi dalam hal seni tari yang melarang perempuan untuk membawanya. Dalam hal ini, pihak perempuan harus dilibatkan dengan seksama, serta mempertimbangkan manfaat dan mudharat sehingga kebijakan yang dihasilkan tidak bias gender.

Berbicara seperti apakah kebijakan publik yang ideal, menurut Nugroho, hal utama yang harus diperhatikan dalam setiap kebijakan yang dilahirkan adalah harus kontekstual atau harus sesuai dengan tantangan yang dihadapi saat ini dan saat yang akan datang. Dalam bahasa Ian Patrick Agustin adalah sebuah kebijakan yang pragmatism. Dalam logika yang sederhana, model seperti ini bisa disetarakan dengan kondep "untung-rugi" dari sebuah kebijakan atau konsep cost benefit ala Boardman. Tentu saja, pemahamannya pertama kali harus dalam bingkai etikal, yaitu berbicara nilai kebaikan dan keburukan. Pragmatism disini mengacu pada 
keharusan dari setiap ide untuk merujuk pada konsekwensi implementasinya. Pragmatism lebih dekat dengan goal setting theory, yaitu setiap kebijakan harus mengacu pada satu tujuan. Pragmatisme juga bersifat etis (ditujukan untuk kepentingan public, bukan kepentingan elit, bukan pula kepentingan sekelompok orang atau segolongan saja) dan bersifat strategis yang mengacu pada tiga ukuran, pertama, memiliki tujuan, kedua mengacu pada konteks tantangan hari ini dan masa depan, dan ketiga sesuai dengan sumber daya yang dimiliki (Nugroho, 2012: 273275).

Kesimpulan sederhana adalah kebijakan publik yang baik adalah kebijakan public yang membangun keunggulan bersaing dari setiap pribadi rakyat tanpa membedakan antara laki-laki dan perempuan, setiap keluarga Indonesia, setiap organisasi, baik pemerintah maupun masyarakat.

\section{E. Pelarangan Seni Tari; Sebuah Kebijakan Yang Ideal?}

Merujuk pada konsep pragmatism yang ditawarkan Ian Patrick Agustin dalam menganalisa kebijakan yang akan diterapkan oleh Bupati Aceh Utara, maka pertanyaan pertama yang muncul adalah apakah kebijakan yang akan diambil bersifak kontekstual atau dalam bahasa Nugroho kita harus melihat konsep "untung-rugi". Kebijakan yang kontekstual disini bisa diartikan kebijakan yang sesuai dengan tantangan yang dihadapi dewasa ini. Nugroho mengartikan pragmatism dalam bingkai etika yang berbicara nilai keburukan dan kebaikan. Mari kita lihat bagaimana nilai-nilai yang terkandung dalam seni tari yang dibawakan oleh para perempuan dewasa. Bagi saya, kaum wanita dengan perangai yang lemah lembut bisa lebih sensitive dalam menghayati setiap kisah yang bercerita dalam seni tari tersebut. Taste tarian lebih bisa didapatkan karena perempuan biasanya lebih lihai dalam hal mengaduk emosi para penikmat seni.

Kemudian, ketika mereka mempelajari dan mengekspresikan performa pertunjukan seni tari, sama artinya mereka sedang melestarikan kebudayaan, memperkenalkan kebudayaan daerah dan juga mengaplikasikan fungsi seni tersebut dalam kehidupan. 
Kemudian, apakah kebijakan yang akan diterapkan nantinya menguntungkan atau mewakili kebutuhan public atau hanya mewakili kepentingan elit. Inilah yang disebut Nugroho dengan pragmatisme bersifat etis. Public Aceh Utara ada yang menilai, rencana sang Bupati hanya untuk mengalihkan isu dan membuat sensasi sesaat sehingga publik terlena dan melupakan isu krusial lainnya semisal kegagalan Bupati dalam mensejahterakan rakyatnya terkait dengan kebijakan yang strategis yang mengacu pada tiga ukuran.

Pertama, memiliki tujuan. Dalam hal ini, kita bisa melihat kaum perempuan yang melakukan seni tari adalah mereka-mereka yang perduli dengan kebudayaan daerah sehingga mereka mau melestarikannya demi menunjukkan identitas kedaerahan. Disamping itu, pertunjukan seni tari merupakan bentuk dari kreatifitas para perempuan yang pada hakikatnya merupakan bagian dari pemberdayaan masyarakat melalui seni pertunjukan.

Kedua, mengacu pada konteks tantangan hari ini dan masa depan. Bagi para praktisi seni, mereka adalah orang-orang yang mempertahankan budaya lokal sebagai hasil kecerdasan kolektif yang mengisi ruang kosong peradaban bangsa. Jika tidak dipertahankan dan dilestarikan, maka tidak menutup kemungkinan akan tergerus zaman dan hilang ditelan globalisasi, dimana arus budaya bisa bebas terinternalisasi dalam sebuah kebudayaan, karena hari ini, batas-batas geografis bukan lagi sebuah permasalahan dalam internalisasi kebudayaan.

Ketiga, sesuai dengan sumber daya yang dimiliki. Dalam hal ini, ketika perempuan diberikan kebebasan dalam pertunjukan seni tari, maka sama halnya dengan peningkatan sumber daya manusia yang ada atau optimalisasi sumber daya manusia. Kesimpulan sederhana adalah kebijakan publik yang baik adalah kebijakan public yang membangun keunggulan bersaing dari setiap pribadi rakyat tanpa membedakan antara laki-laki dan perempuan, antar berbagai ras, agama, dan latar belakang yang berbeda.

Para elit lokal hari ini biasanya memiliki usaha untuk tampil dan membedakan diri dengan pemimpin sebelumnya. Salah satu cara yang mereka gunakan adalah dengan mendukung atau menggangkat isu-isu lokal yang kontraproduktif yang 
disponsori oleh kelompok sosial konservatif, acap kali yang bersifat religious, sehingga membuat mereka terjebak ke dalam perangkap pemimpin yang apparatchik $^{4}$ (Suryakusuma, 2012: 414)

\section{F. Penutup}

Kita berharap dengan keberadaan otonomi daerah, pemerintah daerah seharusnya bisa berbuat lebih dalam hal memajukan kebudayaan daerah melalui kebijakan-kebijakan kebudayaan yang memiliki target, tujuan, standar dan grand design yang jelas, yang berefek pada majunya budaya bangsa, sehingga menempatkan kebudayaan daerah pada derajat yang tinggi karena itu merupakan identitas bangsa yang harus dijaga, dilestarikan serta dimanfaatkan untuk kepentingan masyarakat.

Penjaringan partisipasi semua kalangan menjadi pertimbangan logis dalam hal menentukan sebuah kebijakan. Dengan demikian, masyaratakat yang nantinya juga sebagai objek kebijakan tersebut bisa menerima dan merasa memiliki tanpa harus resah akan nilai-nilai yang menjadi substansi dari kebijakan tersebut. Kesesuaian dengan kebutuhan publik juga bagian yang tak bisa dipisahkan dalam menetukan kebijakan. Kemudian, melihat bagaimana reaksi publik juga menjadi pertimbangan lainnya, jika reaksi yang muncul lebih banyak yang kontra, maka besar kemungkinan kebijakan tersebut tidak diperlukan sehingga arus protes dari berbagai kalangan muncul secara massif. Jika reaksi publik tidak diindahkan, maka bisa jadi akan berdampak sistemik pada stabilitas daerah dan marwah pemimpin itu sendiri. Terakhir, memastikan keterwakilan perempuan dalam merumuskan kebijakan menjadi sebuah keniscayaan, apalagi segala kebijakan yang berkaitan dengan dunia perempuan.

\footnotetext{
${ }^{4}$ Apparatchik adalah istilah dalam bahasa pergaulan sehari-hari yang berasal dari bahasa Rusia. Istilah ini mengacu pada pejabat rendah atau menengah yang memegang jabatan birokratis, namun hanya bisa mengurus hal-hal kecil, bukan kebijakan tingkat tinggi. Istilah ini bernuansa merendahkan dan menggambarkan bahwa seseorang menduduki posisi tertentu karena kesetian ideologis atau politisnya, bukan karena kecakapan atau kualifikasi profesionalnya (Suryakusuma, 2012: 414).
} 
Dalam konteks ke-aceh-an, kita tidak boleh membiarkan adanya monopoli intrepetasi agama melalui wajah Syariah Islam sehingga menyebabkan matinya peran agama itu sendiri. Sempitnya peran agama dalam bentuk formalitas dan simbol, telah memberikan kesan bahwa peran agama di Aceh telah tereduksi sedemikian rupa (Ahmad, 2012: 154-155). Jika pun kebijakan pelarangan tari berbasis pada nilai keagamaan, maka solusi teknis sebagai alternative harus dipikirkan oleh pembuat kebijakan, misalnya, para penari harus menggunakan pakaian adat yang longgar sehingga lekuk tubuhnya tidak terlihat, tidak menghias diri secara berlebihan, atau penari perempuan hanya boleh tampil dalam ruang eksklusif yang hanya disaksikan oleh penonton di kalangan terbatas. Jangan sampai pelarangan terhadap seni tari menjadikan anak cucu kita nantinya tidak pernah tahu jika di Aceh pernah memiliki kekayaan dan warisan budaya seni tari yang luar biasa. 


\section{Daftar Pustaka}

Ahimsa Putra, Heddy. 2013. Budaya Bangsa, Jati Diri dan Integrasi Nasional; Sebuah Teori. Majalah Jejak Nusantara (I).

Ahmad, Kamaruzzaman Bustamam. 2012. Acehnologi. Banda Aceh: Bandar Publishing.

Alimah. 2013. "Lagi, Perempuan dalam Cengkeram Kebijakan Diskriminatif (Menyoal Larangan Prempuan Ngangkang)". Diakses dari http://kppri.or.id/index.php/id/artikel/11-perempuan-dalam-cengkeramankebijakan-diskriminatif pada tanggal 26 juni 2014.

Anderson, James E. 2006. Public Policy Making: An Introduction. Boston: Houghton Mifflin.

Aulia, Hermanto (tt). Macam Macam Tarian Indonesia Diakses dari http://www.scribd.com/doc/45274304/Macam-Macam-Tarian-Indonesia pada tanggal 26 Juni 2014.

Bisnisaceh.com, 27 Mei 2013. "Larangan menari di Aceh Utara jangan diterapkan setengah hati". Diakses dari http://www.Bisnisaceh.com/umum/la rangan-menari-di-aceh-utarajanganditerapkan-setengahhati/index.php pada $\mathrm{t}$ anggal 26 Juni 2014.

Djelantik, A.A.M. 1999. Estetika: Sebuah Pengantar. Bandung: Masyarakat Seni Pertunjukan Indonesia.

Hasjmy, Ali. 1990. Sejarah Kebudayaan Islam di Indonesia. Jakarta: Bulan Bintang.

http://khabarsoutheastasia.com, 1 Juni 2013. "Kontroversi meletus atas larangan menari di Aceh". Diakses dari http://khabarsoutheastasia.com/id/ar ticles/apwi/articles/features/2013/06/01/feature-02. pada tanggal 26 Juni 2014.

Kesuma, Asli, dkk. 1991. Diskripsi Tari Saman Propinsi Daerah Istimewa Aceh. Departemen Pendidikan Dan Kebudayaan Kanwil Propinsi Daerah Istimewa Aceh.

Kompas.com, 25 mei 2013. "Bupati Aceh Utara Larang Perempuan Menari", diakses dari http://regionalkompas.com/read/2013/05/25/16500817/Bupati.AcehUtara. Larang.Perempuan.Menari pada tanggal 26 Juni 2014. 
Kompas.com, 26 mei 2013. "Larangan Wanita Menari di Aceh Utara Tak Berdasar". Diakses dari http://regional.kompas.com /read/ 2013 /05/26/15332918/Larangan. Wanita. Menari. di.Aceh.Utara. Tak.Berdasar pada tanggal 26 Juni 2014.

Nugroho, Riant. 2012. Public Policy; Dinamika Kebijakan, Analisis Kebijakan, Manajemen kebijakan. Jakarta: PT. Elex Media Komputindo Kompas Gramedia.

Okongwu, Anne Francis dan Mencher, Joan P. 2000. "The Anthropology of Public Policy: Shifting Terrains Author". Annual Review of Anthropology, Vol. 29 (2000), pp. 107-124. Diakses dari http://www.jstor.org/stable/223417 Accessed: 02/11/2009 04:53

Shore, Cris and Wright, Susan. 2005. Anthropology of Policy: Critical Perspectives on Governance and Power. London: Routledge.

Simatupang, Lono Lastoro. 2013. "Pengelolaan Kebudayaan: Sinergitasi Pemangku Kepentingan". Makalah disampaikan dalam Kongres Kebudayaan Indonesia pada tanggal 8-11 Oktober. Yogyakarta.

Sudarsono. (tanpa tahun). Tarian-Tarian di Indonesia 1, Jakarta: Proyek Pengembangn Media Kebudayaan Direktoran Jenderal Kebudayaan Depdikbud.

Suryakusuma, Julia. 2012.Agama, Seks dan Kekuasaan. Jakarta: Komunitas Bambu.

Winarno, Budi. 2005. Teori dan Proses Kebijakan Publik. Yogyakarta: Media Pressindo.

www.bbc.co.uk, 27 mei 2013. "Pernyataan Bupati Aceh Utara yang melarang perempuan dewasa menari di depan khalayak, menuai kritikan". Diakses dari http://www.bbc.co.uk/indonesia/berita_indonesia/2013/05/1305 27_aceh_tari_perempuan.shtml, tanggal 26 Juni 2014 